\title{
BIO-MASS ENERGY PRESENT SCENARIO
}

\author{
Ajit, Harshita Kumari, Kashish Sharma \\ E-Mail Id: ajit@anandice.ac.in \\ Department of Electrical Engineering Anand International College of Engineering, Jaipur, Rajasthan, \\ India
}

\begin{abstract}
As the demand of energy is increasing now- a days, it is estimated that by the year 2030, India's dependency on fossil fuels import exceeds $53 \%$ of country's total energy consumption. India is the world's 7 th largest producer of energy and 5th largest energy consumer [1]. In any economy there is direct effect of per capita energy consumption on per capita income and degree of economic growth. So, to balance the amount of fossil fuels and maintain the economy of India the energy should be generated using renewable sources or say non-conventional sources of energy. This paper includes the study of possibilities of electrical power generation by bio mass, as it can help for the rural electrification. If we particularly talk about Rajasthan then in year 2019, the installed capacity of Rajasthan is approx. 21GW and total increase during year 2018-19 is $1524.87 \mathrm{MW}$ [2].
\end{abstract}

Keywords- Bio- Mass, Bio - Energy, Steam Turbine.

\section{INTRODUCTION}

India is an agricultural country with approximately 84 Crore people live in rural area out of 121 Crore. The major activities of rural population are production, processing and selling of agricultural products [3]. Energy is the lifeline of major activities in India. In India mostly the energy demands are largely dependent on fossil fuels. These fossil fuels. These fossil fuels are mostly imported to India [ 4]. And in case of Rajasthan, the Rajasthan is providing more electricity than other states like UP, Maharashtra, Punjab \& Haryana [ 5].

In India about $68.4 \%$ of energy is generated using non renewable energy sources which are also now limited in amount and continuous use of these sources will extinct them. So, to prevent them renewable sources like solar energy, wind energy, biomass energy, small hydro power plant is established to fulfill the need of energy. Only $31.6 \%$ of energy is generated using renewable sources. Among these 705 of rural population depends on Bioenergy for their domestic usage in our country.

\section{BIO-ENERGY}

It is carbonaceous organic waste from animals and plants; it generally refers to the agricultural waste likes stalks, stems, shell etc. It also contains combination of waste and sewage. It is considered as renewable energy source because it can be replenished by growing new crops. It is better alternative than the coal. Bio mass is used in India for cooking and heating mainly in the rural areas.

However due to lack of awareness about the proper and efficient use of biomass is not used up to its full potential. The same is applicable for urban areas, here the municipal solid waste is generated on huge quantities but a very little amount of it is used properly. India is a developing country and every day millions of tons of such waste management and waste to energy policy. This will not only help to handle the waste properly but also generate electricity along with other benefits [9].

Now let us see in detail the sources of biomass production of biogas, production of electricity, cost of per unit, pollution control, waste management and other advantages.

Many developed and developing countries has promoted biomass energy generation through instrumented policies and financial incentives.

India is a fast-developing country; with high economic and industrial growth energy demand is also growing. The major source fulfills the energy requirement of India are oil and coal. The energy consumption of India using these conventional sources are $151.3 \mathrm{GW}$ by thermal (coal, natural gas and oil) $4.78 \mathrm{GW}$ by nuclear energy, $30.49 \mathrm{GW}$ by hydro and $27.54 \mathrm{GW}$ by renewable energy.

The energy which is obtained by organic matter is known as bio-energy.

\subsection{Biogas}

To obtain biogas, cow dung is put into Gobar Gas Plant. There are over 4.5 million household biogas plant mainly for producing cooking fuel in India. India is the 2nd largest producer of biogas plant in world.

\subsection{Bio-Mass}

This is the important source of energy for India. It is a fuel that we obtain from organic materials. Around 32\% of our country's total primary energy comes from biomass. Also, more than $70 \%$ of our population depends on it for their energy requirement.

\subsection{Need of Bio Mass Energy}

Bio mass has been used as a fuel since malennia, until the mid-19th century, biomass dominated the global energy consumption with rapid increase in fossil fuels use. Share of biomass in total energy has declined steadily over a century. Yet, biomass still contributes $14 \%$ of the world energy and $38 \%$ energy in development of countries [7]. Also, energy from biomass is reliable as it is free of fluctuation. Unlike wind power and does not need storage to be used in times of non-availability as in case with solar energy. The electricity generation could be cheaper than coal if biomass could be available economically [8]. 
ICRDET-2019, September 14-15, 2019, AICE, Jaipur, India

International Journal of Technical Research \& Science (Special Issue) ISSN No.:2454-2024 (online)

\section{BIOMASS ENERGY IN INDIA}

Growth in energy generation through biomass BIOMASS WIND SOLAR

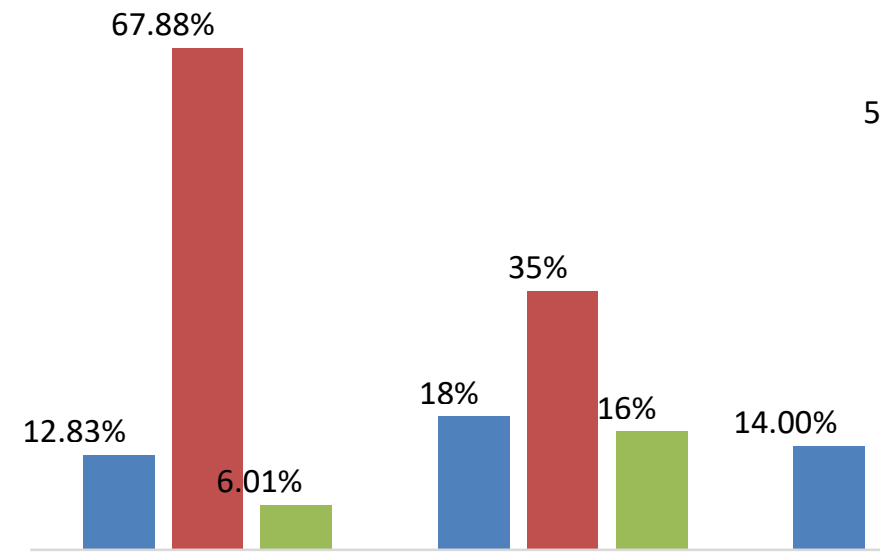

2013

2015
$56 \%$

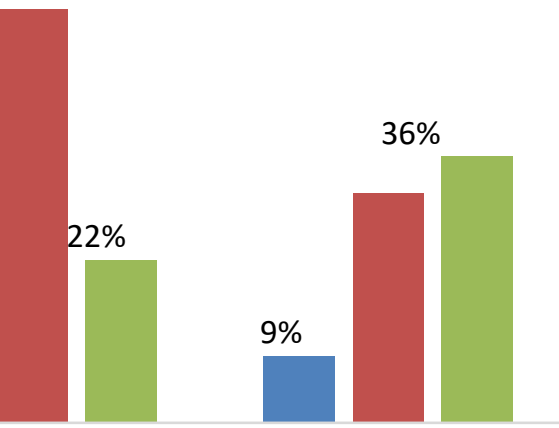

2017

2018

Fig. 3.1 The Current Availability of Biomass in India

The current availability of biomass in India is estimated at about 500 million metric tons per year. Studies sponsored by the Ministry has estimated surplus biomass availability at about $120-150$ million metric tons per annum covering agricultural and forestry residues corresponding to a potential of about 18,000 MW. This apart, about $5000 \mathrm{MW}$ additional power could be generated through bagasse based cogeneration in the country's 550 Sugar mills, if these sugar mills were to adopt technically and economically optimal levels of cogeneration for extracting power from the bagasse produced by them,

$>$ India produces about 450-500 million tons of biomass per year. Biomass provides $32 \%$ of all the primary energy use in the country at present.

$>$ EAI estimates that the potential in the short term for power from biomass in India varies from about $18,000 \mathrm{MW}$, when the scope of biomass is as traditionally defined, to a high of about 50,000 MW if one were to expand the scope of definition of biomass.

$>$ The current share of bio fuels in total fuel consumption is extremely low and is confined government has made mandatory in 10 states. Mainly to $5 \%$ blending of ethanol in gasoline, which the

$>$ Currently, bio-diesel is not sold on the Indian fuel market, but the government plans to meet $20 \%$ of the country's diesel requirements by 2020 using bio- diesel.

$>$ Plants like Jatrophacurcas, Neem, Mahua and other wild plants are identified as the potential sources for bio-diesel production in India.

$>$ There are about 63 million ha waste land in the country, out of which about 40 million ha area can be developed by undertaking plantations of Jatropha. India uses several incentive schemes to induce villagers to rehabilitate waste lands through the cultivation of Jatropha.

$>$ The Indian government is targeting a Jatropha plantation area of 11.2 million ha by 2012 .

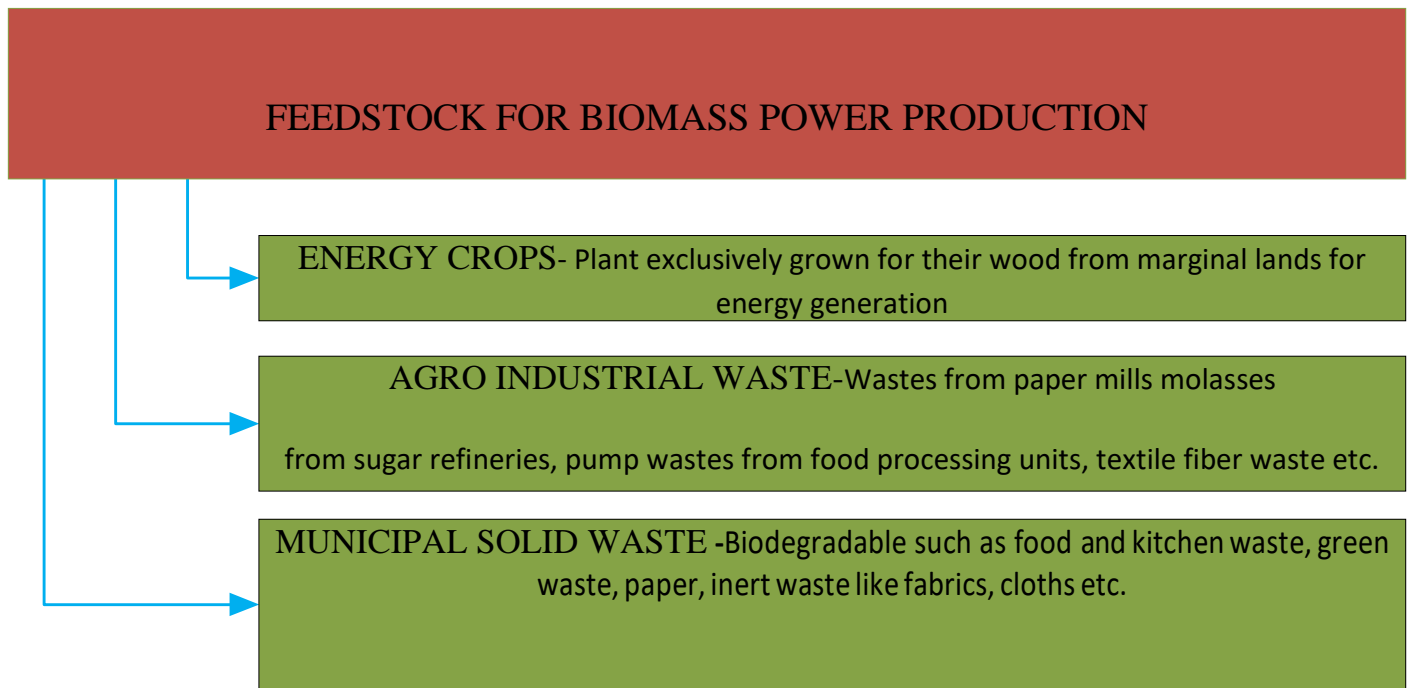

Fig. 3.2 Energy Generation Growth 


\subsection{Bio - Mass Sources}

Biomass sources can be any organic waste from animal, plants and even aquatic. India is a huge agriculturally based country, so agricultural waste is in abundance. Also, there are many forests in India which provide with firewood.

The sources are classified as -

Forest waste: - wood, timber, sawdust, tree branches leave etc.

Agricultural waste: - stalks, stems, fiber, rice husks, etc.

Animals waste: - cow dung, poultry waste, sewage etc.

Aquatic waste: - Alga, water hyacinth, weeds sea grass, kelp, coral etc.

Other waste: - waste from food processing industries, municipal wastes, industrial wastes etc.

\subsection{Types of Biomass}

Biomass is highly diverse in nature and classified on the basis of site of origin, as follows:

$>$ Field and plantation biomass

$>$ Industrial biomass

$>$ Forest biomass

Urban waste biomass

$>$ Aquatic biomass

\subsection{There Are Five Fundamental Forms of Biomass Energy Use}

$>$ The "traditional domestic" use in developing countries (fuel wood, charcoal and agricultural residues) for household cooking (e.g. the "three stone fire"), lighting and space-heating. In this rolethe efficiency of conversion of the biomass to useful energy generally lies between 5\% and $15 \%$.

$>$ The "traditional industrial" use of biomass for the processing of tobacco, tea, pig iron, bricks \& tiles, etc, where the biomass feedstock is often regarded as a "free" energy source. There is generally little incentive to use the biomass efficiently so conversion of the feedstock to useful energy commonly occurs at an efficiency of $15 \%$ or less.

> "Modern industrial." Industries are experimenting with technologically advanced thermal conversion technologies which are itemized below. Expected conversion efficiencies are between 30 and $55 \%$.

$>$ Newer "chemical conversion" technologies ("fuel cell") which are capable of by-passing the entropy- dictated Carnot limit which describes the maximum theoretical conversion efficiencies of thermal units.

> "Biological conversion" techniques, including anaerobic digestion for biogas production and fermentation for alcohol.

> In general, biomass-to-energy conversion technologies have to deal with a feedstock which can be highly variable in mass and energy density, size, moisture content, and intermittent supply. Therefore, modern industrial technologies are often hybrid fossil-fuel/biomass technologies which use the fossil fuel for drying, preheating and maintaining fuel supply when the biomass supply is interrupted.

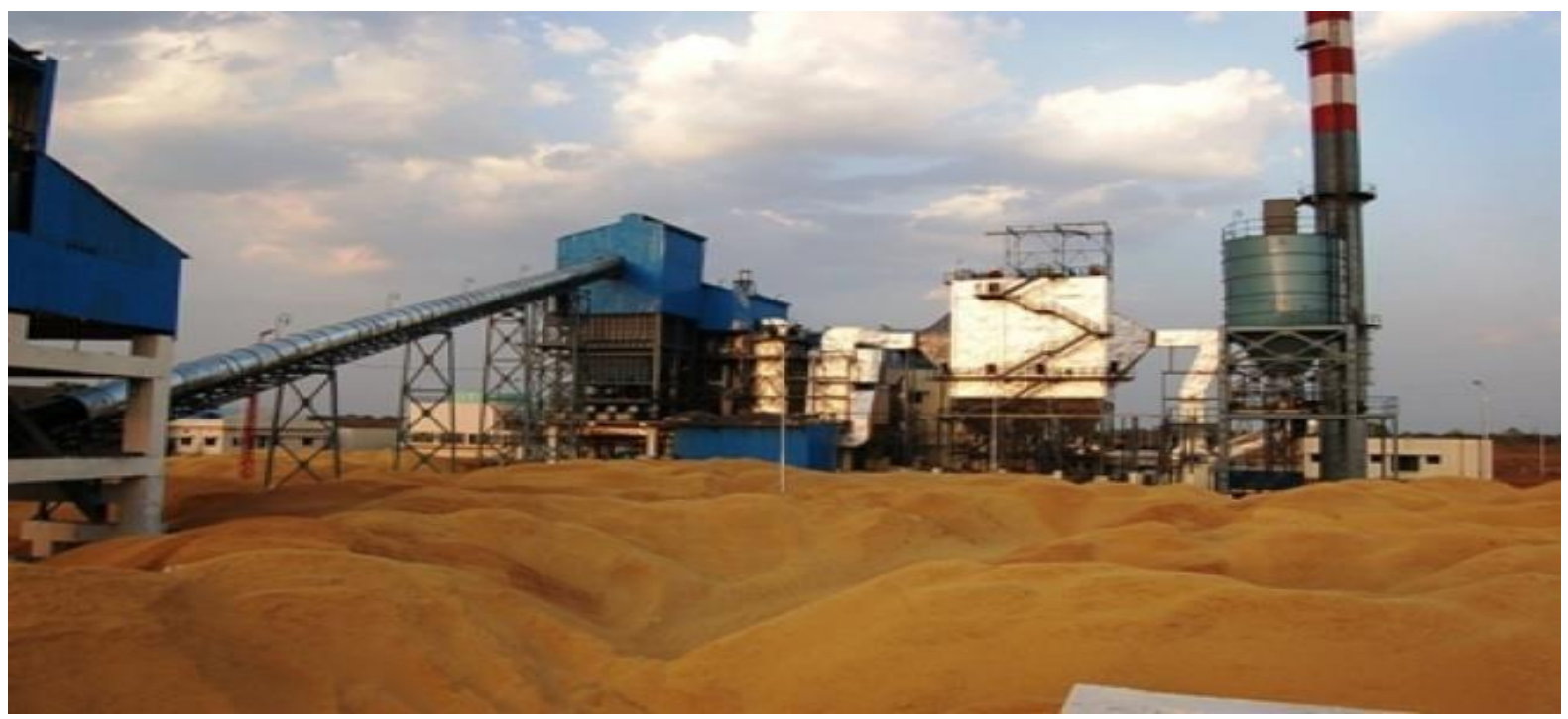

Fig. 3.3 10 MW Biomass Power Project, Gadchiroli, Distt. MH

3.4. State Wise Cumulative Achievement of Biomass Power and Cogeneration Projects is as Follows

Considering the present status of biomass-based power generation and thermal applications, it is expected that only about 30-35 million tons of surplus biomass is being used annually for the existing and ongoing biomass projects.

*Capacity includes projects of both Andhra Pradesh and Telangana. 
ICRDET-2019, September 14-15, 2019, AICE, Jaipur, India

International Journal of Technical Research \& Science (Special Issue) ISSN No.:2454-2024 (online)

Table-3.1 State Wise Biomass Power Generation

\begin{tabular}{|c|c|}
\hline \\
\hline \multicolumn{2}{|c|}{$\begin{array}{c}\text { State Wise Biomass Power and Cogeneration Projects } \\
\text { State }\end{array}$} \\
\hline Andhra Pradesh* & 389.75 \\
\hline Bihar & 43.42 \\
\hline Chhattisgarh & 264.90 \\
\hline Gujarat & 55.90 \\
\hline Haryana & 52.30 \\
\hline Karnataka & 737.28 \\
\hline Madhya Pradesh & 36.00 \\
\hline Maharashtra & $1,112.78$ \\
\hline Odisha & 20.00 \\
\hline Punjab & 140.50 \\
\hline Rajasthan & 111.30 \\
\hline Tamil Nadu & 662.30 \\
\hline Uttarakhand & 30.00 \\
\hline Uttar Pradesh & 936.70 \\
\hline West Bengal & 26.00 \\
\hline Total & $4,761.00$ \\
\hline
\end{tabular}

\section{GLOBAL SCENARIO OF BIOMASS ENERGY}

Biomass is an important energy source contributing to more than $14 \%$ of the global energy supply. About $38 \%$ of such energy is consumed in developing countries, primarily in the rural and traditional sectors of the economy.

In 2009, biomass production contributed 3.9 quadrillion Btu of energy to the 73.1 quadrillion Btu of energy produced in the United States or about $5.3 \%$ of total energy production.

The U.S. and Brazil produced about 89 percent of the world's fuel ethanol in 2008 out of total world production of $17335 \mathrm{MW}$.

In terms of energy content, the total annual production of biomass is estimated at 2,740 Quads (1 Quad = $10,000,000,000,000,000$ Btus). Biomass production is about eight times the total annual world consumption of energy from all sources (about 340 Quads). Therefore, biomass represents a very large energy resource. At present the world population uses only about $7 \%$ of the annual production of biomass. Therefore, we are only partially exploiting nature's abundant renewable resource.

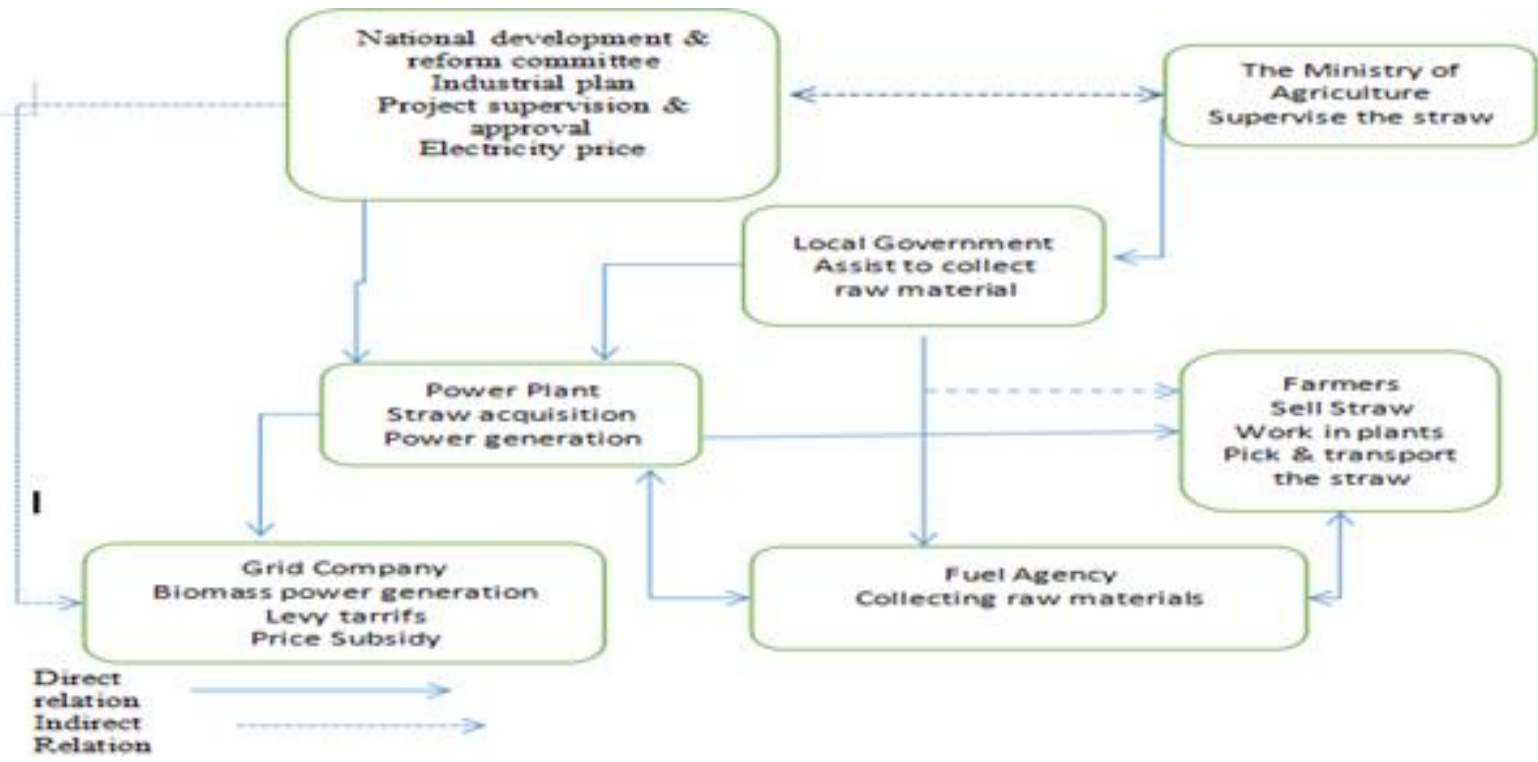

Fig. 4.1 Operation framework of Biomass Power Generation

Manufacturing capability exists in the country for the equipment/machinery required for setting up Biomass Projects. Except for some critical control equipment, most of the equipment $\mathrm{s}$ can be procured from indigenous sources.

DOI Number: https://doi.org/10.30780/specialissue-ICRDET-2019/004 


\subsection{Boilers}

Number of large manufacturers have established capabilities for manufacturing spreader stoker fired, traveling grate/dumping grate boilers; atmospheric pressure fluidity bed boilers and circulating fluidity bed boilers. Due to recent upsurge of interest in co-generation for surplus power, leading manufacturers are further upgrading their capabilities for high efficiency boilers.

\subsection{Steam Turbines}

Almost all combinations condensing, single extraction/double extraction condensing, back pressure, etc. are now being manufactured in the country with full after sales services. The efficiencies of turbines now being offered are comparable to the best in the world.

\subsection{Other Equipment}

Apart from the main equipment, there is a well- established capability and capacity for manufacture of related equipment for use of biomass for energy including harvesters, balers, briquetting equipment, handling and firing equipment, pollution control systems etc. Many multinational companies have set up manufacturing facilities in the country for such equipment.

\section{REFERENCES}

[1] MNRE: Renewable energy in India growth and targets, May 2019. http/: mnre.gov.in.

[2] CEA; Installed capacity; http/: cea.nic.in.

[3] E. Omar, A. R. Haitahm and B. Frede, "Renewable energy resources current status, future prospectus and their enabling technology," Renewable and Sustainable Energy Reviews, vol. 30, pp. 748-764, 2014.

[4] A. Kumar, N. Kumar, P. Baredar and A. Shukla, "A review on biomass energy resources, potential, conversion and policy in India," Renewable and Sustainable Energy Reviews, vol. 45, pp. 530-539, 2015.

[5] N. Golait, R. M. Moaril and P. S. Kulkarni, "Wind electric power in the world and perspective of its development in India," Renewable and Sustainable Energy Reviews, vol. 13, pp. 233-247, 2009.

[6] P. Abhishek "India 2020: Utilities \& Renewable," Deutsche Bank Markets Research. Available: https://www.db.com/cr/ en /docs/ Deutsche-Bank- report-Make-way-for-the-Sun. pdf. 2015.

[7] B. Mehmet, O. Arif, B. Sahin and A. Kahraman, "An overview of renewable electric power capacity and progress in new technologies in the world," Renewable and Sustainable Energy Reviews, vol.49, pp. 323334, 2015.

[8] Borowitzka, Michael A., and Navid Reza Moheimani. "Open pond culture systems." In Algae for Biofuels and Energy, pp. 133-152. Springer Netherlands, 2013.

[9] Kais, Md Imran, Farsad Imtiaz Chowdhury, and Kazy Fayeen Shahriar. "Biodiesel from Microalgae as a solution of third world energy crisis." In World Renewable Energy Congress, pp. 192-199. 2011.

[10] Athanasios A. Rentizelas, Athanasios J. Tolis and Ilias P. Tatsiopoulos, "Logistics issues of biomass: The storage problem and the multi-biomass supply chain”, Science Direct, Renewable and Sustainable Energy Reviews 13 (2009) pp 887-894. 